\title{
Crop Yield Comparisons of Different Soil treatments and Changing pyrethroids Rates on Daucus carota in Mauritius
}

\author{
Vedendranand Sharma Chummun, and Geeta Devi Somaroo
}

\begin{abstract}
Agriculture contributes in the gross domestic product (GDP) and the creation of jobs in most African countries. However, there is a decline in the quality of soil in nearly half of the lowincome countries, especially in the arid or semi-arid regions of Africa. Moreover, the continent's agricultural sector depends largely on rainwater in order to sustain plant growth and development. In an effort to adapt to challenges facing the agricultural sector, governmental and non-governmental organizations have consistently promoted chemical fertilizers as a yield augmenting technology. Moreover, the extensive use of chemical pesticides in agriculture has also led to an increase in pest' resistance, serious environmental contamination, toxic residue accumulation and negative impacts on non-target organisms coupled with the extinction of certain beneficial organisms. Many unsustainable agricultural systems have led to soil degradation mainly through loss of organic matter leading to a decrease in soil fertility. Sustainable agriculture refers to an agricultural production and distribution system that encompasses diverse methods of farming that is more profitable, environmentally sound, and that is good for communities. Such practices integrate natural biological cycles, control, protect and renew soil fertility, while optimizing on-farm resources and reducing purchased production inputs, particularly non-renewable resources. A study based on the effect of Pyrethroid pesticides on Carrot (Daucus carota) for different soil treatments was carried in two regions in Mauritius namely Triolet (Sub Humid) and Ripailles (Super Humid). The study compared the impacts of MSW Compost, Farmyard manure and Chemical fertilizers on the yield of carrot (Daucus carota) and the effect of increasing two selected pesticides from the pyrethroids group of pesticides on carrots and their subsequent consequence on plant growth and yield. Carrots were grown under seven different treatments namely: T1 (Soil only), T2 (Soil and compost), T3 (Soil, compost and pesticides at recommended rate), T4 (Soil, compost and three times recommended rate of pesticides), T5 (Soil, manure and fertilizer), T6 (Soil, manure, fertilizer and pesticides at recommended rate) and T7 (Soil, manure, fertilizer and pesticides at three times recommended rate) The results showed that for both region 1 and region 2, T3, where the recommended rate of pesticides used (1.0 $\mathrm{mL} / \mathrm{L}$ Deltamethrin and $0.5 \mathrm{~mL} / \mathrm{L}$ Cypermethrin), obtained a higher yield than $\mathrm{T} 4$, where the dosage of pesticides was tripled $(3.0 \mathrm{~mL} / \mathrm{L}$ Deltamethrin and $1.5 \mathrm{~mL} / \mathrm{L}$ Cypermethrin). For pesticide level in carrot crops, values obtained for Cypermethrin and Deltamethrin for treatment T4 and T7 exceeded the Maximum Residue Limits by more than $20 \%$ in most cases. The study at both experimental sites suggested that the utilization of compost as soil amendment and
\end{abstract}

Vedendranand Sharma Chummun, and Geeta Devi Somaroo are with Open University Of Mauritius, Mauritius bioremediation agent which can improve soil quality and boost crop yield.

Keywords — compost, chemical fertilizer, pesticides, manure, soil.

\section{INTRODUCTION}

$\mathrm{T}$ HE Agricultural sector has been known to ensure food security in any society across the ages in human history. However, its greatest challenge has been in countenance to climate change, mainly due to anthropogenic activities. These alterations include soil and water contamination, increase in atmospheric carbon dioxide concentration and air temperature, changes in precipitation and prevalence of extreme climate events [1]. Consequently, the price of being unsustainable predictably gears towards a decrease in the availability and quality of resources, principally soil and water, which essentially contribute to food production. As speculated by [2], this lurking global threat impacts on the objective of [3] where Agricultural production systems are expected to produce food for a global population, will reach nine billion people in 2050 [4]. Our current soil management strategies are mainly dependent on the indiscriminate use of agrochemicals, particularly, inorganic chemical-based fertilizers, inevitable to meet the increasing demand for food $[5,6]$. According to [7], the factors contributing to soil degradation includes wind and water erosion along with chemical degradation, by improper use of chemical pesticides and fertilizers. This causes the loss of soil organic matter and soil nutrients thus decreasing soil fertility and hence, crop yield and quality. Degraded soils and groundwater have limited resiliency and transform chemicals, which can become mobile and bioavailable to organisms, posing ecological risks that may not only threaten the existence of plants and animals but also human health [8]. As a matter of fact, it is imperative that a sustainable approach of integrated agricultural systems should be implemented to address adaptation to climate change, food security and land degradation [9]. According to [10], soil quality is the capacity of a soil to function, within ecosystem and land use boundaries, to sustain productivity, maintaining environmental quality, and promote plant and animal health. Therefore, the management of organic amendments and mineral fertilizers could have a major impact on soil fertility 
and quality status, influencing the quantity and quality of organic residues and nutrient inputs entering the soil and the rate at which the residues and organic matter decompose [11, 12]. Most literatures show that biofertilizers, specifically, compost have proven to keep the soil environment rich in all kinds of micronutrients and macronutrients, encouraging carbon sequestration and soil moisture retention, increased crop yield and economic net benefits while reducing soil erosion, pest and disease incidence [5, 13, 14, 15].

\section{Methodology}

The methodology presents two experimental trials carried out simultaneously in Mauritius on two different study sites in both summer and winter to investigate the impact of chemical and non chemical soil amendments and selected pesticides on the yield of carrot (Daucus carota).

The evaluation of the impacts of different soil amendments on Daucus carota which is a very common vegetable and is of particular importance in terms of vitamins was carried out. Carrot also forms part of the strategic action plan of the Mauritian Government to increase and improve food security on the island and to reduce importation of widely consumed vegetables.

\section{Study Site}

The study assessed the growth and yield of carrots on the impacts of different soil amendments, in two different extreme agro climatic conditions in Mauritius; sub humid and super humid. Region one, Triolet $\left(20.05^{0} \mathrm{~S}, 57.55^{\circ} \mathrm{E}\right)$, is a sub humid region located in the northern part of Mauritius, receiving less than $1200 \mathrm{~mm}$ of rainfall yearly and the soil type is latosolic red prairie soil. Region two, Ripailles $\left(20^{\circ}\right.$ 11 ' 45.3' E $57^{0} 34^{\prime} 54.2$ ' E), is a super humid region, located in the central part of Mauritius, receiving around $2600 \mathrm{~mm}$ of rainfall annually and the soil type is latosolic brown forest soil. The two selected sites were not subjected to any excessive application of fertilizers or pesticides and were only used for backyard gardening purposes.

\section{Experimental design}

The study comprised of analyzing different soil treatments, Soil only (S), MSW Compost and Soil (SC), MSW Compost, soil and pesticides at recommended rate (SCP), MSW Compost, soil and pesticides at three times recommended rate (SCP3), Manure, Fertilizer and Soil (SMF), Manure, fertilizer, soil and pesticides at recommended rate (SMFP) and Manure, Fertilizer, Soil and pesticides at three times recommended rate (SMFP3) on crop yield and growth of carrot. Prior to the experiment, an initial laboratory analysis was conducted to determine the characteristics of the soil at both study sites. The $\mathrm{pH}$, Electrical conductivity, N, P, K contents, organic carbon, calcium and magnesium content were determined. The seven different treatments and their application rates on soil were determined in relation to the equivalent nitrogen, potassium, and phosphorous (NPK) contents that the different soil amendments could provide to the crop as shown in table 1.

TABLE 1: APPLICATION RATES OF THE DIFFERENT TREATMENTS

Treatments
Soil only (S)
Soil and MSW Compost (SC)
Soil, MSW Compost and pesticides at recommended rate (SC
Soil, MSW Compost and pesticides at three times recommen
(SCP3)
Soil, Manure and Fertilizer (SMF)
Soil, Manure, Fertilizer and pesticides at recommended rate (S)
Soil, Manure, Fertilizer and pesticides at three times recom
rate (SMFP3)

Fig. 1a: displays the bed set up of the experimental trial

An area of $50 \mathrm{~m}^{2}$ was earmarked at Triolet and Ripailles to carry out the experimental trials. The land was carefully marked. A length of $3 \mathrm{~m}$ and a breadth of $1 \mathrm{~m}$ were carefully measured. Each bed was of size $3 \mathrm{~m} \times 1 \mathrm{~m}$, and a path of 50 $\mathrm{cm}$ in between. The soil was sampled in both regions to carry out the initial soil analysis after which the various soil amendments were added accordingly. Carrot was sown using the broadcast method. The beds were irrigated with the help
Application Rate

Bare soil - control

33t/ha MSW Compost

33t/ha MSW Compost

Pesticides: Deltamethrin: $1.0 \mathrm{~mL} / \mathrm{L}$, Cypermethrin $0.5 \mathrm{~mL} / \mathrm{L}$

33t/ha MSW Compost

Pesticides: Deltamethrin: 3.0mL/L, Cypermethrin $1.5 \mathrm{~mL} / \mathrm{L}$

30t/ha Manure, Fertilizer 13:13:20:2 250kg/ha

30t/ha Manure, Fertilizer 13:13:20:2 250kg/ha

Pesticides: Deltamethrin: 1.0mL/L, Cypermethrin $0.5 \mathrm{~mL} / \mathrm{L}$

30t/ha Manure, Fertilizer 13:13:20:2 250kg/ha

Pesticides: Deltamethrin: $3.0 \mathrm{~mL} / \mathrm{L}$, Cypermethrin $1.5 \mathrm{~mL} / \mathrm{L}$

of a watering can just after sowing and after that sprinkler irrigation system was used. Pesticides were sprayed as from the fourth week of the crop cycle and spraying was continued every 7 days until the end of the crop cycle. During the growing period, soil temperature and plant height were measured at regular intervals.

\section{Statistical Analyses}

Crop yield was compared with the three different assumptions. Statistical analyses were performed using IBM SPSS. Data were input in the right form and in all cases an ANOVA single factor was run. The independent variables being yield in all cases and dependent variables being study sites, seasonality and pesticide dosage correspondingly. The significance was set at $\mathrm{p}<0.05$. 


\section{RESUlts AND DisCUSSIONS}

\begin{tabular}{|c|c|c|c|c|c|c|c|c|c|}
\hline Parameters & & Total & & $\begin{array}{l}\text { Organic Carbon } \\
(\%)\end{array}$ & $\begin{array}{l}\mathrm{Ca} \\
(\mathrm{g} / \mathrm{Kg})\end{array}$ & $\begin{array}{l}\mathrm{Mg} \\
(\mathrm{mg} / \mathrm{Kg})\end{array}$ & $\begin{array}{l}\mathbf{p H} \\
\left(\mathbf{H}_{2} \mathbf{0}\right)\end{array}$ & $\begin{array}{l}\mathrm{EC} \\
(\mu \mathrm{S})\end{array}$ & $\begin{array}{l}\text { pH - } \\
\text { After }\end{array}$ \\
\hline Sample & $\mathbf{N}(\%)$ & $\mathbf{P}(\mathbf{p p m})$ & K (me\%) & & & & & & \\
\hline Region 1 summer & 0.29 & 191 & 1.01 & 23.4 & 11.2 & 5567 & 7.35 & 262 & 7.50 \\
\hline Region 1 winter & 0.22 & 201 & 1.09 & 23.0 & 12.8 & 6799 & 7.40 & 243 & 7.35 \\
\hline Region 2 summer & 0.35 & 2187 & 1.38 & 3.3 & 12.9 & 1418 & 6.04 & 256 & 5.98 \\
\hline Region 2 winter & 0.37 & 2177 & 1.49 & 3.4 & 16.7 & 2397 & 6.70 & 267 & 6.14 \\
\hline
\end{tabular}

It has been reported that to grow crops the soil is needed to be reinforced with large amounts of $\mathrm{N}, \mathrm{P}$ and $\mathrm{K}$ to sustain convenient crop production. Soil $\mathrm{pH}$ is important because it can affect the availability of plant nutrients as well as the soil ecology. In very acid or alkaline soils some plant nutrients convert to forms that are more difficult for plants to absorb. This can result in nutrient deficiencies. In some cases if the exact increase of soil $\mathrm{pH}$ happens, this leads to large increase in nutrient availability close to the roots [16]

Table 3A illustrated that $\mathrm{pH}$ for region 1 was closer to 7 being neutral whereas $\mathrm{pH}$ for region 2 was lower than 7 , being slightly acidic. Rain prone areas normally have acidic $\mathrm{pH}$. The rain washes away carbon dioxide to form weak acids [17]. Major $\mathrm{pH}$ extreme require soil corrections but here the $\mathrm{pH}$ was according to the norms. Another important parameter is the soil electrical conductivity. It is a measurement that correlates with soil properties that affect crop productivity, including soil texture, cation exchange capacity (CEC), drainage conditions, organic matter level, salinity, and subsoil characteristics. The presence of $\mathrm{N}, \mathrm{P}$ and $\mathrm{K}$ is noted in the two different soil types but no indication is provided on the availability of these elements. $\mathrm{Ca}$ and $\mathrm{Mg}$ are important elements needed for plant growth and development. Magnesium is present in larger amount in region 1 in comparison to region 2. Magnesium is normally washed away in rain prone areas and this explains the deficit.

\section{Soil Temperature variations}

It was observed that there was a gradual decrease in soil temperature when the experiment progressed. This was basically explained by the fact that there was a steady change from summer to winter. Also, the temperatures recorded at region 2 were much lower than that recorded in region 1 . Region 1 being a sub humid region located along the coastal areas of the island is much warmer whereas region 2 being a super humid region is located on the central plateau and is much colder and rainier.

\section{Plant height}

The plant height is one of the most basic indications of a healthy plant. The carrot leaves were measured on week 5, 7 and 10. The observations in the early stage, mid stage and final stage did reflect the same. The control was shortest in height. Treatments subjected to fertilizer applications yielded taller plants. Applying three times pesticide dosage did not show an increase in plant height. In most cases, the plant height noted was lower than the treatment subjected to recommended rates of pesticides. The same observations were customary for both study sites. It was generally observed that in winter the plants were taller as compared to in summer.

TABLE 3B: YIELD OF CARROTS

\section{$\begin{array}{ll}\text { SUMMER } & \text { WINTER }\end{array}$}

\begin{tabular}{|c|c|c|c|c|c|c|c|}
\hline \multicolumn{2}{|c|}{ TRIOLET (Sub humid) } & \multicolumn{2}{|c|}{ RIPAILLES (Super humid) } & \multicolumn{2}{|c|}{ TRIOLET (Sub humid) } & \multicolumn{2}{|c|}{ RIPAILLES (Super humid) } \\
\hline Treatment - Replicate & Yield $t / h a$ & Treatment-Replicate & Yield $\mathrm{t} / \mathrm{ha}$ & Treatment - Replicate & Yield t/ha & Treatment - Replicate & Yield $\mathrm{t} / \mathrm{ha}$ \\
\hline T1 & 15 & $\mathrm{~T} 1$ & 16 & $\mathrm{~T} 1$ & 14 & $\mathrm{~T} 1$ & 15 \\
\hline T2 & 18 & $\mathrm{~T} 2$ & 17 & $\mathrm{~T} 2$ & 17 & $\mathrm{~T} 2$ & 18 \\
\hline T3 & 21 & T3 & 22 & $\mathrm{~T} 3$ & 20 & $\mathrm{~T} 3$ & 21 \\
\hline T5 & 21 & T5 & 22 & T5 & 20 & T5 & 21 \\
\hline T6 & 23 & T6 & 24 & T6 & 24 & T6 & 23 \\
\hline T7 & 22 & $\mathrm{~T} 7$ & 22 & $\mathrm{~T} 7$ & 24 & $\mathrm{~T} 7$ & 20 \\
\hline
\end{tabular}

Carrots were harvested at maturity (after 12 weeks), and the weight for each treatment was carefully weighed using a weighing balance. Table $3 \mathrm{~b}$ illustrates the yield obtained for each treatment at the two different study sites in winter and summer. In some cases the yields of carrot harvested at Ripailles were higher when compared to that at Triolet. Ripailles is a super humid region benefiting from higher rainfall as compared to Triolet which is a sub humid region. So, even though under rainfed conditions, carrots grown at 
Ripailles were higher in yield as there was ample water for plant development and growth. Water forms part of the full crop requirement; if the right amount of water is provided, this can increase crop growth and crop yield [18]. Carrots grown under treatment 1 , where no fertilizers and soil amendments were added, resulted in producing stunted plants and also short and small carrots.

\section{Yield and study sites}

Very often the yield is affected if subjected to various climatic conditions. An ANOVA single factor was run to compare the yields from the sub humid and super humid region. The results of the ANOVA demonstrated $p$ value of 0.878 ( $\mathrm{p}>0.05)$, thus concluding that there was no significant difference in yield across the different study sites. The two study sites may be have been subjected to different climatic conditions but the results of the yield did not demonstrate any considerable disparity. This non significant result reflects that carrots could be grown well in the two contrasted climatic conditions.

\section{Yield and seasonality}

Yields were also compared across the seasonality. As such an ANOVA single factor was run to investigate the effect of changing seasonality on carrot yields. The $\mathrm{p}$ value was 0.846 ( $p>0.05$ ), thus greater than 0.05. This demonstrated that there was no significant difference between yields of carrots across seasonality. Very often seasonal climates are prevalent with different conditions. In Mauritius summer gives in higher rainfall than in winter. Yet, amidst all these differences, the anova showed non-significant results.

\section{Yield and pesticides dosage}

Yields of carrots were compared while increasing the pesticides dosage, from zero to recommended and from recommended to three times recommended for both pesticides applied. An Anova single factor having dependent variable yield and independent variables dosage of pesticides was run on SPSS. The $\mathrm{p}$ value was less than 0.05 , concluding that there was significant difference in yield across dosage. The change was mostly visible when changing from zero to recommended rate of pesticides. As shown in table 4.3 and 4.4, there was a more visible increase in yield from $\mathrm{T} 1$ to $\mathrm{T} 3$, $\mathrm{T} 2$ to $\mathrm{T} 3$ and $\mathrm{T} 5$ to T6, where the dosage of pesticide increased from zero to recommended rate. For this an increase of $21.7 \%$ in terms of yield was observed. For T3 to
$\mathrm{T} 4$ and $\mathrm{T} 6$ to T7, the increase was no much and in some cases there was also a decrease in yield when moving from the recommended rate of pesticides to three times recommended rates of pesticides. In most cases the decrease of yield was $5 \%$. Increasing dosage of pesticides could harm beneficial insects responsible to promote plant growth and development [19], and this mainly impacted in this study showing that excessive pesticides application did not increase crop yield. Yet, applying the right dosage was useful in promoting optimum plant growth and development.

Across all treatments subjected to the two study sites, different agroclimatic conditions and seasons, treatment $\mathrm{T} 1$ produced the lowest yield. The reason was principally that no soil amendments were used to enrich the soil and also no pesticides were applied to control the incidence of pests and diseases. Crop production cannot be sustained only by nutrients present naturally in soils, bearing the fact that Mauritian soils are very weak in nutrient availability. Treatment $\mathrm{T} 2$ obtained yield slightly higher than T1. Yields increased by $15 \%$ from $\mathrm{T} 1$ to $\mathrm{T} 2$. $\mathrm{T} 3$ was subjected to compost application together with the pesticides at recommended dosage $(1.0 \mathrm{~mL} / \mathrm{L}$ Deltamethrin and $0.5 \mathrm{~mL} / \mathrm{L}$ Cypermethrin); and in most cases the yield more than $10 \%$ higher as compared to $\mathrm{T} 4$, where the same rate of compost was used but pesticides dosage was increased by three fold (3.0mL/L Deltamethrin and $1.5 \mathrm{~mL} / \mathrm{L}$ Cypermethrin). Excessive pesticides usage causes pesticides - mediated toxicity which tends to affect plant growth [20]. The same scenario was observed for $\mathrm{T} 6$ and $\mathrm{T} 7$, where $\mathrm{T} 6$ with the recommended rate of pesticides $(1.0 \mathrm{~mL} / \mathrm{L}$ Deltamethrin and $0.5 \mathrm{~mL} / \mathrm{L}$ Cypermethrin) obtained more than $10 \%$ higher yield than $\mathrm{T} 7$, where three times recommended rate of pesticides $(3.0 \mathrm{~mL} / \mathrm{L}$ Deltamethrin and $1.5 \mathrm{~mL} / \mathrm{L}$ Cypermethrin were used.

Compost is said to have the ability to degrade pesticides in soil [21]. Consequently, the carrots grown on treatments of compost application (T3, T4) detected lower levels of pesticides than carrots cultivated on manure and fertilizer application (T6, T7). In summer T3 detected $0.47 \mathrm{ppm}$ of cypermethrin at region 1 compared to $0.90 \mathrm{ppm}$ for T6. For $\mathrm{T} 4,0.22 \mathrm{ppm}$ of deltamethrin was detected as compared to $0.73 \mathrm{ppm}$ for $\mathrm{T} 7$ in region 2 . Table $3 \mathrm{C}$ shows how the detection of pesticides were lowered in compost subjected treatments as compared to synthetic fertilizer treated soils

TABLE 3C: COMPARISON BETWEEN COMPOST, FERTILIZER AND MANURE SUBJECTED TREATMENTS

SUMMER WINTER

\begin{tabular}{llllllllll}
\hline T & \multicolumn{2}{c}{ TRIOLET (Sub humid) } & \multicolumn{2}{c}{ RIPAILLES (Super humid) } & \multicolumn{2}{c}{ TRIOLET (Sub humid) } & \multicolumn{2}{c}{ RIPAILLES (Super humid) } \\
& \multirow{2}{*}{ Cypermethrin } & Deltamethrin & Cypermethrin & Deltamethrin & Cypermethrin & Deltamethrin & Cypermethrin & Deltamethrin \\
& $\mathbf{3}$ & 0.47 & 0 & 0.35 & 0.07 & 0.26 & 0 & 0.54 & 0 \\
$\mathbf{4}$ & 1.46 & 0.18 & 1.49 & 0.22 & 2.44 & 0.28 & 1.59 & 0.34 \\
$\mathbf{6}$ & 0.90 & 0 & 0.45 & 0.08 & 0.40 & 0.05 & 0.55 & 0.05 \\
$\mathbf{7}$ & 4.18 & 0.68 & 3.24 & 0.73 & 2.48 & 0.58 & 2.24 & 0.54 \\
\hline
\end{tabular}


Fertilizers and manure amendments (T6, T7) had higher levels of cypermethrin and deltamethrin as compared to compost subjected treatments (T3, T4). It can be suggested that compost can act as a natural slow release pesticide system thus diminishing the pesticides level uptake by the carrots on the compost treated plots [22]. Nevertheless, bioaccumulations of these chemicals have been reduced by the application of compost. Moreover it was found that compost addition resulted in significant increases in pesticides inactivation in contaminated materials with the possibility of gearing towards bioremediation [23].

The results from the study revealed that treatments subjected to fertilizer and manure application produced greater yield of carrots but the use of compost reduced pesticide uptake in carrots by helping the rapid degradation of pesticides in soil. Increasing the rate of pesticide was not directly proportional to plant yield as this caused toxicity which resulted in stunted plant growth, thus decreased plant yield. Yield did not vary significantly across study sites and seasonality. For pesticide dosage, things were different. There was a considerable change in yield, more than $10 \%$ in most cases where the shift was from zero pesticides dosage to recommended rate of pesticides. But, from recommended rate to three times recommended rate there was no major change in yield and in some cases the yield were $5 \%$ lesser.

\section{CONCLUSION}

The study analyzed the effect of exceeding the recommended dosage of pesticides on carrots. As already stated, in order to maximize yield, farmers usually increase the amount of pesticides dosage in their fields. Based on the results obtained for the two experimental trials, it was concluded that the use of compost reduced pesticide uptake in carrots by helping the rapid degradation of pesticides in soil. Previous studies have revealed that the microorganisms present in compost break down these contaminants in the soil, while transforming these into humus and inert byproducts, such as carbon dioxide, water, and salts. Further analyses on effect of pesticides on soil quality and food crop are still under scientific investigation.

These findings showed that Mauritius can reduce the importation of inorganic fertilizers for food crop production. Farmers should be encouraged to decrease the amount of chemical fertilizers utilization in their fields, which are the main cause of soil impoverishment with time and move towards more sustainable application through the integration of compost in soil so as to preserve and regenerate the soil organic matter content. The use of compost in farming will cause a significant decrease in the cultivation cost of production for vegetables, fruits and even sugarcane. But, the main challenge is the mindset of farmers where they only believe that only synthetic fertilizers can increase plant yield.

\section{REFERENCES}

[1] K.Y. Chan. Climate Change on Soil Structure and Soil Health: Impacts and Adaptation. In Singh, B.P, Cowie, A.L., Chan, K.Y. (Eds) Soil Health and Climate Change. Springer-Verlag. Berlin. pp. 49-68, 2011 http://dx.doi.org/10.1007/978-3-642-20256-8_3

[2] R. Lal. Rationale for Watershed as a Basis for Sustainable Management of Soil and Water Resources. In Lal, R. (Ed.) Integrated Watershed Management in the Global Ecosystem. CRC Press. USA. pp. 3-16, 2000

[3] UNFPA. The state of the world population report. By choice, not by chance: family planning, human rights and development. United Nations Population Fund, New York, 2012

[4] G. Branca, L. Lipper, N. McCarthy, M. C. Jolejole. Food security, climate change, and sustainable land management: A review. Agronomy for sustainable development, 33(4), 635-650, 2013 http://dx.doi.org/10.1007/s13593-013-0133-1

[5] D. Bhardwaj, M. W. Ansari, R. K. Sahoo, N. Tuteja. Biofertilizers function as key player in sustainable agriculture by improving soil fertility, plant tolerance and crop productivity. Microbial Cell Factories, 13, 66, 2014

http://dx.doi.org/10.1186/1475-2859-13-66

[6] D. Mishra, S. Rajvir, U. Mishra, S. S. Kumar. Role of bio-fertilizer in organic agriculture: a review. Research Journal of Recent Sciences, 2(ISC-2012), 39-41, 2013.

[7] C. Sejwar. Sustainable Agriculture in $21^{\text {st }}$ Century with Special Reference to Land Degradation. In Singh, T. (Ed.) Resource conservation and food security, Vol. 1. pp. 385-394, 2004. Concept Publishing. India.

[8] D. C. Adriano, A. Chlopecka, D. I. Kaplan, H. Clijsters, J. Vangronsveld. Soil contamination and remediation: philosophy, science and technology. Les Colloques de l'INRA, 465-504, 1997

[9] E. Bryan, C. Ringler, B. Okoba, J. Koo, M. Herrero, S. Silvestri. Can agriculture support climate change adaptation, greenhouse gas mitigation and rural livelihoods? insights from Kenya. Climatic Change, 118(2), $151-165,2013$

http://dx.doi.org/10.1007/s10584-012-0640-0

[10] J. W. Doran, and T.B. Parkin. Defining and assessing soil quality. In: J.W. Doran, Coleman, D.F., Bezdicek, D.F., Stewart, B.A. (Eds.) Defining soil quality for a sustainable environment. SSSA Special Publication No. 35. SSSA, Madison, WI.7. pp. 3-21, 1994 http://dx.doi.org/10.2136/sssaspecpub35.c1

[11] C. Giacometti, M. S. Demyan, L. Cavani, C. Marzadori, C. Ciavatta, E. Kandeler. Chemical and microbiological soil quality indicators and their potential to differentiate fertilization regimes in temperate agroecosystems. Applied Soil Ecology, 64, 32-48, 2013 http://dx.doi.org/10.1016/j.apsoil.2012.10.002

[12] M. H. Gerzabek, R. S. Antil, I. Kögel-Knabner, H. Knicker, H. Kirchmann. How are soil use and management reflected by soil organic matter characteristics: a spectroscopic approach. European Journal of Soil Science, 57(4), 485-494, 2006

http://dx.doi.org/10.1111/j.1365-2389.2006.00794.x

[13] J. Martínez-Blanco, C. Lazcano, T. H. Christensen, P. Muñoz, J. Rieradevall, J. Møller, A. Assumpció, A. Boldrin . Compost benefits for agriculture evaluated by life cycle assessment. A review. Agronomy for sustainable development, 33(4), 721-732, 2013. http://dx.doi.org/10.1007/s13593-013-0148-7

[14] S. Brown, M. Cotton. Changes in soil properties and carbon content following compost application: results of on-farm sampling. Compost Science \& Utilization, 19(2), 87-96, 2011 http://dx.doi.org/10.1080/1065657X.2011.10736983

[15] P. Crisp, G. Baker, S. Wheeler. Agronomic and Sustainability Outcomes from Compost Application in South Australian Citrus Orchards. ISHS Acta Horticulturae, 1018, 457-464, 2011

[16] M. Bagayoko, S. Alvey, G. Neumann, A. Buerkert. Root-induced increases in soil $\mathrm{pH}$ and nutrient availability to field-grown cereals and legumes on acid sandy soils of Sudano-Sahelian West Africa. Plant and Soil 225: 117127,2000 http://dx.doi.org/10.1023/A:1026570406777

[17] D. Bickelhaupt D. Soil pH: What it means. Department of Forest and Natural Resources Management. State University of New York College of Environmental Science and Forestry, 2016

[18] J. Doorenbos, A. H. Kassam, C. L. M Bentvelsen, V. Brancheid, J. M. G. Alusje, M. Smith, G. O. Uittenbogaard, H. K. Van Der Wal H.K. Yield Response to water. Food and Agricultural Organization, Irrigation and Drainage Paper 33, 1986

[19] A. M. Klein, B. E. Vaissiere, J. H. Cane, I. Steffan-Dewenter, S. A. Cunningham, C. Kremen, T. Tscharntke . Importance of pollinators in changing landscapes for world crops. Proceedings of the Royal Society of London. Series B, Biological Sciences, 274, 303-313, 2007 http://dx.doi.org/10.1098/rspb.2006.3721 
[20] M. Ahemad, M. S. Khan. Ecological assessment of biotoxicity of pesticides towards plant growth promoting activities of pea (Pisum sativum)-specific Rhizobium sp. strain MRP1. Emir. J. Food Agric. 24 (4): 334-343

[21] E. Karanasios, D. G. Karpouzas and N. G. Tsiropoulos. Key parameters and practices controlling pesticide degradation efficiency of biobed substrates. Journal of Environmental Science and Health, Part B, 47(6), 589-598, 2012.

http://dx.doi.org/10.1080/03601234.2012.665753

[22] R. G. Sinclair. Slow-release pesticide system. Polymers of lactic and glycolic acids as ecologically beneficial, cost-effective encapsulating materials. Environmental Science \& Technology, 7(10), 955-956, 1973 http://dx.doi.org/10.1021/es60082a011

[23] M. A. Cole, Z. Liu, X. Liu. Remediation of pesticide contaminated soil by planting and compost addition. Compost Science \& Utilization, 3(4), 2030, 1995

http://dx.doi.org/10.1080/1065657X.1995.10701804 